\title{
The system of professional development and assessment of the competencies of university teaching staff to ensure quality education in the interests of sustainable development of society: a case study of Russia
}

\author{
Elena Razinkina, Olga Kalinina*, and Elena Zima \\ Peter the Great St.Petersburg Polytechnic University, 195251, Polytechnicheskaya Str., 29, \\ St.Petersburg, Russia
}

\begin{abstract}
This article substantiates the need to form a comprehensive system of professional development and assessment of teachers' competencies in order to ensure quality education in the interests of sustainable development of society. The main goals and objectives are formulated and the methodological tools developed by the authors for the formation of this system are described. The features of the implementation of the system in the practice of conducting the educational process at Peter the Great St. Petersburg Polytechnic University (St. Petersburg, Russia) are revealed. The risks are identified and recommendations for their minimization are given for other educational organizations of higher education that implement a comprehensive system of professional development and assessment of the competencies of teachers using digital services.
\end{abstract}

\section{Introduction}

One of the priority Sustainable Development Goals developed by the UN General Assembly for the period up to 2030 is to ensure inclusive and equitable quality education and promote lifelong learning opportunities for the whole of society [1]. According to the "Report on Human Development in the Russian Federation. The United Nations and Russia Sustainable Development Goals" one of the strategic objectives for the implementation of this goal in the Russian Federation is to ensure the availability of high-quality vocational and higher education, including university education" [2]. According to the UNESCO concept [3], sustainable development cannot be achieved solely through information technology, political regulation or financial mechanisms. There is a need to provide quality education and training for sustainable development at all levels and regardless of social conditions. The main role in this process is assigned to the higher education system, which forms the country's human capital.

\footnotetext{
*Corresponding author: olgakalinina@bk.ru
} 
Increasing the level of education of the population leads to maintaining a high status of higher education. The most important role in this process is assigned to the teaching staff-the driving force of the development of higher education. This sets the task of forming and improving the mechanisms of independent assessment of qualifications in the formation of the educational policy of universities. In accordance with the Strategy for the Development of the national qualifications system of the Russian Federation until 2030 [4] one of the main directions for the development of the national qualifications system in our country is the formation of mechanisms to encourage citizens and employers to master and use modern qualifications, which determines the need to provide opportunities for the development and confirmation of the required qualifications to students of secondary vocational and higher education organizations. At the same time, one of the main challenges in the field of skills development in the Russian Federation is the accelerated digitalization of economic and social life, which has exacerbated the demand for digital competencies of employees, whose role in the new conditions has significantly increased.

The above-mentioned global and national priority goals and objectives contribute to the modernization of Russian higher education, which is characterized by high socio-social requirements in combination with modern economic conditions and digital transformation. All this leads to the need to improve the quality of the educational process, which in turn forms a special claim of society to the level of competence of university teachers. The introduction of new educational programs that meet modern requirements and the needs of society entails a change in the understanding of the structure of pedagogical skills, which includes a wide range of professional, socio-personal and managerial competencies of a teacher. At the same time, the current competitive selection procedures in the higher education system for filling vacant teaching positions are often quite formal. There is an objective need to develop and implement additional mechanisms that would turn the process of evaluating the teacher's performance into an effective tool for developing his / her professionalism in response to the challenges of the needs of sustainable development of society.

Such a tool at Peter the Great St. Petersburg Polytechnic University (SPbPU) is a comprehensive system of professional development and assessment of the level of competence of teaching staff in the format of a voluntary teacher certification procedure, the main purpose of which was to improve the quality of the educational process throughout the years of students' education.

\section{Materials and methods}

The theoretical framework and methodological basis for the development and implementation of a comprehensive system of professional development and assessment of the level of teachers' competencies in the format of voluntary certification are the works of foreign and Russian scientists and practitioners working in the field of education quality assessment: Swuste P., Galera A. et al. [5], Fahim A., Tan Q. et al. [6], Vesce E., Cisi M. et al. [7], Pham P.-T., Duong T.-B. et al. [8], Kinzie J. [9], Jiang, Y., Zhang, J. et al. [10], Bondarenko A.V. [11], Druzhinina A.V. [12], Keshikov K. A. [13], Pazukhina S. V., Ignatovich V. G. [14], Tskvitaria T. A. [15], Shabanova Yu. V., Akinshina I. V. [16].

Voluntary certification of teachers, as one of the elements of assessing the quality of teachers' activities within the framework of an internal independent assessment of the quality of education, was developed and implemented by a group of Russian researchers involved in the formation and implementation of the innovative educational policy of SPbPU under the leadership of the Vice-Rector for Educational Activities, professor Razinkina E. M. [17-20].

Peter the Great St. Petersburg Polytechnic University became the first university in Russia to develop and implement such a system in the regular practice of certification procedures, 
since it allows not only to establish the formal compliance of teachers with the requirements of the federal state educational standards of higher education, the requirements for personnel conditions for the implementation of educational programs, and the unified qualification directory of positions of managers, but also to determine the quality of teaching staff, building an effective system of professional improvement of teachers based on the results obtained.

Thus, the main goal of this system is to apply an integrated approach to the professional development and evaluation of teaching staff, which allows measuring and improving the level of competencies in the context of the strategic goals of the university, dictated by the external environment.

In accordance with this goal, the current tasks are:

identifying the prospects for the professional growth of teachers,

stimulating the improvement of professional competence of teachers,

personnel planning in the field of professional development,

professional training or retraining of teachers,

formation of a managerial personnel reserve, the main purpose of which is to promote teachers to senior positions and provide opportunities for career planning for teachers,

professional development of teachers and strengthening of motivation of work.

Voluntary teacher certification includes an assessment of the quality of teaching in four certification modules:

normative legal module-knowledge of the normative legal field of the teacher's activity,

digital competence module-ability to work in the transforming digital environment of the university,

professional module-knowledge of the material in the subject field of teaching,

communication module-knowledge of the techniques of effective presentation of the material, organization of interaction with students.

The first three modules are implemented in the form of testing; the communication module includes an independent survey of students.

To prepare teachers for voluntary certification, such programs of professional development of SPbPU teaching staff as "Regulatory and legal support of educational activities in the higher education system", "Digital environment of an educational organization", "Public speaking in scientific and educational activities" have been developed and are being implemented. Teachers can be trained in one, two or three advanced training programs, or they can be tested without mastering the corresponding programs. In case of successful completion of advanced training programs in the regulatory legal module and the digital competencies module, the results obtained are re-credited as part of the certification for the corresponding module with the maximum score.

The system of professional development of teachers at SPbPU through the implementation of advanced training programs uses the author's competence approach in the development of the infrastructure for the professionalization of teachers, contributes to the rapid and effective adaptation of new employees, the constant development and build-up of their competencies, and the preservation of the professional tone of teachers with experience.

The knowledge and skills acquired in the framework of advanced training allow teachers to freely apply the norms of the labor legislation of the Russian Federation and the legislation on education, local regulations of the university, to work in the transforming digital environment of the university, participating in the solution of the strategic tasks facing it.

According to the results of successful completion of the voluntary certification, teachers are issued a certificate with a validity period of 3 years.

Voluntary certification of teachers is integrated into the current incentive system successful completion of the certification allows teachers to receive additional points in accordance with the Regulation on the Rating of Teaching Staff under an effective contract, which contributes to the total amount of points scored by teachers in order to determine 
personal increasing coefficients for increasing their official salaries. This is comparable, for example, to the points awarded for a scientific publication in publications indexed in the scientometric databases Scopus and Web of Science. At the same time, points for passing the voluntary certification are awarded during the entire period of validity of the certificate.

The set of advanced training programs, as well as modules for certification, is not accidental and is determined not only by the qualification requirements imposed on the teacher within the current legislation, i.e. formalized (knowledge of the regulatory legal framework of higher education and the ability to apply it in practice), but also by the modern realities of the transforming digital society (digital competencies, the ability to learn in cooperation, etc.). At the same time, it is important to note that if the development of advanced training programs on regulatory legal support and digital competencies gives the teacher a quick result already this year, then the development of the program "Public Speeches in scientific and educational activities" gives a delayed result, since the improvement of the teacher's communication skills cannot be instantly reflected in the results of the student survey.

Conceptually, the creation of a comprehensive system for assessing the level of professional competencies of teachers through voluntary certification can be divided into two stages.

The first stage-experimental-includes the following main activities:

development of the concept and local regulatory framework for the voluntary certification procedure,

development of professional development programs for teachers associated with certification modules of voluntary certification,

development and external review of the bank of questions for the three certification modules of the voluntary certification system, the questionnaire for students on the evaluation of teachers' activities,

development of digital services to ensure the implementation of certification modules using the learning management system (LMS) platform - for conducting testing procedures and surveys, analyzing and recording results,

development of the procedure, organization and testing of the procedure for voluntary certification of teachers at experimental sites (selective educational structural units of the university),

development of a model of certificates for teachers who have successfully passed the certification,

accounting for the results of passing the voluntary certification in the system of effective contracts based on the construction of the rating,

summing up the results of the experiment, publishing the results, finalizing the system of voluntary certification, including taking into account the reviews of teachers who have passed the certification, and external reviewers.

The second stage - the main one - involves the implementation of the following measures:

mass introduction of the procedure for voluntary certification of teachers in all educational structural divisions of the university,

organization of professional development of teachers who have expressed a desire to be prepared for the voluntary certification.

To create and implement a comprehensive system of professional development and assessment of the level of competence of teachers, it is desirable to have a structural unit that deals with the assessment of the quality of educational activities. Employees involved in the implementation of this system must have basic knowledge, skills and abilities in the field of evaluation and development of personnel involved in the implementation of educational programs. 
At SPbPU, conducting an independent evaluation of the teaching staff through a voluntary certification procedure in the interests of professional development of employees is one of the tasks of the university's education quality center.

The organization and implementation of voluntary certification of teachers, as well as accounting for its results, are implemented through the digital service "Working Office of a scientific and pedagogical employee" and the electronic information and educational environment of the university.

\section{Results and discussions}

Testing of the system of voluntary certification of teachers has confirmed its effectiveness. During the testing in the 2017/2018 academic year, 187 teachers of two SPbPU institutes passed the voluntary certification procedure. Since the 2018/2019 academic year, voluntary certification has been introduced into the regular practice of evaluating teachers throughout the university; 1009 teachers from 14 Institutes and Higher schools participated in this procedure, $95 \%$ of teachers successfully passed this procedure and received certificates with a validity period of 3 years.

In the 2019/2020 academic year, the certification of teachers was carried out on a university-wide scale, since almost all teachers passed the voluntary certification procedure at the previous stages, and their certificates have not yet expired, 364 applications were submitted, but due to the force majeure situation associated with the transition of the university to a distance learning format as part of measures to prevent the spread of the new coronavirus infection COVID-19, 257 teachers were tested, including 54 full-time and 203 people - remotely with the installation of specialized software Safe Exam Browser. 239 teachers were certified and received certificates, which was $93 \%$ of the teachers who took part in the voluntary certification procedure. At the same time, 98 people used the right to transfer the results of advanced training in the normative legal module, and 76 teachers used the digital competencies module.

In the 2020/2021 academic year, the voluntary certification procedure was mainly attended by novice teachers, who were elected for the first time by competition. The results of the voluntary certification of teaching staff in 2020/2021 are presented in table 1.

Table 1. The results of the voluntary certification of teaching staff, 2020/2021 academic year.

\begin{tabular}{|l|c|}
\hline Total passed, pers., including: & $\mathbf{1 7 7}$ \\
\hline full-time & 175 \\
\hline remotely & 2 \\
\hline Certified for the full term, people & $\mathbf{1 7 0}$ \\
\hline Certified for a reduced term, people & $\mathbf{4}$ \\
\hline Not certified, pers. & 3 \\
\hline Transfer of professional development results as a regulatory module, people & 48 \\
\hline Transfer of professional development results as a digital competence module, pers. & 44 \\
\hline
\end{tabular}

Based on the results of the external expertise, the developed comprehensive system of professional development and assessment of the level of competence of teachers in 2018 was supported by the federal state budgetary institution "National Accreditation Agency in the Field of Education". And in 2020, the SPbPU project "Integrated system of professional Development and Assessment of the competencies of teachers in the management of university personnel" won first place in the nomination "Best Personnel Technology for Personnel Assessment" at the competition "Best Personnel Technologies of St. Petersburg2020".

It is important to note that the increase in the level of digital competencies of teachers has increased the "purity" of information in the automated systems of the university (the 
correctness of filling out profiles in scientometric databases, digital services, etc.), in addition, it has facilitated the transition of the university to an exclusively distance learning format in the electronic information and educational environment in the context of the pandemic. Improving the level of normative legal and digital literacy, as well as mastering the techniques of effective presentation of material and organizing interaction with students, has improved the quality of the organization and implementation of educational activities in $\mathrm{SPbPU}$ as a whole.

\section{Conclusions}

The system of voluntary certification of teachers developed at Peter the Great St. Petersburg Polytechnic University can be replicated in other educational institutions of higher education that implement a comprehensive system of professional development and assessment of the level of competence of teachers using digital services. Table 2 provides recommendations for minimizing the risks that may arise when implementing this system.

Table 2. The recommendations for minimizing the risks when implementing the system of professional development and assessment of teachers' competencies.

\begin{tabular}{|c|c|c|}
\hline № & Risks & Recommendations \\
\hline 1 & $\begin{array}{l}\text { Risk of complexity in the integration } \\
\text { of various automated accounting and } \\
\text { management systems }\end{array}$ & $\begin{array}{l}\text { Availability of highly qualified personnel involved in } \\
\text { the automation of all information collection and } \\
\text { processing processes, as well as supporting the } \\
\text { information and educational electronic environment } \\
\text { of the educational organization of higher education }\end{array}$ \\
\hline 2 & $\begin{array}{l}\text { The risk of the impossibility of } \\
\text { automation (the possibility of } \\
\text { incomplete automation) of } \\
\text { accounting for quantitative } \\
\text { indicators of labor quality } \\
\text { assessment due to the lack of } \\
\text { automated accounting of a particular } \\
\text { indicator in an educational } \\
\text { organization }\end{array}$ & $\begin{array}{l}\text { The use of the principles of consistency and } \\
\text { interconnectedness that determine the coordination } \\
\text { of the actions of all structural divisions of an } \\
\text { educational organization involved in the } \\
\text { management and design of a comprehensive system } \\
\text { of professional development and evaluation of } \\
\text { teaching staff in the context of digitalization of } \\
\text { education }\end{array}$ \\
\hline 3 & $\begin{array}{l}\text { The risk of an insufficiently high } \\
\text { level of quality of professional } \\
\text { development programs associated } \\
\text { with certification modules of } \\
\text { voluntary certification }\end{array}$ & $\begin{array}{l}\text { Involvement of external experts for the development } \\
\text { and examination of professional development } \\
\text { programs associated with the certification modules } \\
\text { of voluntary certification }\end{array}$ \\
\hline 4 & $\begin{array}{l}\text { Risk of insufficient quality of test } \\
\text { materials for use in the procedure of } \\
\text { voluntary certification of teachers }\end{array}$ & $\begin{array}{l}\text { Involvement of external experts for the development } \\
\text { and evaluation of test materials used in the procedure } \\
\text { of voluntary certification of teachers }\end{array}$ \\
\hline
\end{tabular}

The developed comprehensive system of professional development and assessment of the level of competence of teachers in the format of the procedure of voluntary certification of teachers is an important part of the unified system of independent internal assessment of the quality of educational activities of SPbPU, while ensuring the development of teachers' competencies (professional, socio-personal and managerial) in response to the challenges of modern society to higher education. At the same time, the emphasis is not on the traditionally easily measured scientometric indicators that characterize the research activities of teachers, but on aspects that directly affect the quality of the educational process that provides quality education for graduates, which contributes to the implementation of the fourth UN Sustainable Development Goal "Ensuring inclusive and equitable quality education and promoting lifelong learning opportunities for all" in the interests of sustainable development of society. 


\section{References}

1. Report on the Sustainable Development Goals. - United Nations General Assembly (2020) https://unstats.un.org

2. Report on Human Development in the Russian Federation. The UN and Russian Sustainable Development Goals. - Analytical Center under the Government of the Russian Federation (2016) https://ac.gov.ru

3. Education for sustainable development. - UNESCO (2016) https://ru.unesco.org

4. Strategy for the development of the national qualifications system of the Russian Federation for the period up to 2030. - National Council for Professional Qualifications under the President of the Russian Federation (2021) https://nspkrf.ru

5. P. Swuste, A. Galera, W. Van Wassenhove, D. Wenham, C. Van Den Broeke, Safety Science, 141 (2021)

6. A. Fahim, Q. Tan, B. Naz, Q.U. Ain, S.U. Bazai, Sustainability Switzerland, 13(8) (2021)

7. E. Vesce, M. Cisi, T. Gentile, I. Stura, Quality in Higher Education, 27(1) (2021)

8. P-T. Pham, T-B. Duong, T.-T.-T Phan, V.-T.B. Nguyen, T-T. Nguyen, International Journal of Education and Practice, 8(3) (2020)

9. J. Kinzie, Higher Education Policy, 32(4) (2019)

10. Y. Jiang, J. Zhang, T. Xin, Journal of Educational and Behavioral Statistics, 44(6) (2019)

11. A. V. Bondarenko, Electronic journal "RONO". Innovation: search and research, 16 (2012)

12. A.V. Druzhinina, Humanization of education, 5 (2016)

13. K. A. Keshikov, Prospects for the development of information technologies, 29 (2016)

14. S. V. Pazukhina, V. G. Ignatovich, Pedagogical science and education, 3(16) (2016)

15. T. A. Tskvitaria, International conference Problems and Prospects of Professional Education Development in the 21st Century, Collections of conferences of the SIC Sociosphere, 20 (2016)

16. Yu. V. Shabanova, I. V. Akinshina, International conference «In the world of science and innovation» (Kyrgan, 2016)

17. E. M. Razinkina, O. V. Kalinina, International conference ICT Management for Global Competitiveness and Economic Growth in Emerging Economies, Octo (ICTM) (Wrocław, Poland, 2018)

18. E. M. Razinkina, O. V. Kalinina, Audit and financial analysis, 1 (2019)

19. E. M. Razinkina, K. V. Raev, O. V. Kalinina, St. Petersburg State Polytechnical University Journal. Humanities and Social Sciences, 10(2) (2019)

20. E. M. Razinkina, E. A. Zima, O. V. Kalinina et al., E. Deming's concepts in quality management (2020) 